\title{
Numeracy Level, Mathematics Problem Skills, and Financial Literacy
}

\author{
Edmar E. Indefenso ${ }^{1}$, Alberto D. Yazon ${ }^{2, *}$ \\ ${ }^{1}$ Laguna Science Integrated High School, Department of Education, Philippines \\ ${ }^{2}$ College of Teacher Education, Laguna State Polytechnic University, Philippines
}

Received May 9, 2020; Revised August 3, 2020; Accepted August 25, 2020

\begin{abstract}
Cite This Paper in the following Citation Styles
(a): [1] Edmar E. Indefenso, Alberto D. Yazon, "Numeracy Level, Mathematics Problem Skills, and Financial Literacy," Universal Journal of Educational Research, Vol. 8, No. 10, pp. 4393-4399, 2020. DOI: 10.13189/ujer.2020.081005.
\end{abstract}

(b): Edmar E. Indefenso, Alberto D. Yazon (2020). Numeracy Level, Mathematics Problem Skills, and Financial Literacy. Universal Journal of Educational Research, 8(10), 4393-4399. DOI: 10.13189/ujer.2020.081005.

Copyright $\bigcirc 2020$ by authors, all rights reserved. Authors agree that this article remains permanently open access under the terms of the Creative Commons Attribution License 4.0 International License

\begin{abstract}
The study aimed to identify the correlation of numeracy level and mathematics problem solving ability to the respondents' financial literacy. The correlational research design was used in the study with the scores on the numeracy level and mathematics problem solving skills of the respondents, which were correlated to the scores on financial knowledge, financial behavior, and financial attitude as the domains of financial literacy. There were 563 grade 9 and 10 respondents from Masaya Integrated National High School (MINHS) and Laguna Science Integrated High School (LSIHS). Data were collected using the validated instrument to measure the given variables. This instrument reported an overall reliability index of $\alpha=0.94$. The statistical tools applied for the treatment of data gathered were frequency, percent, mean, and Pearson Product Moment of Correlation Coefficient. The study found out that the respondents have an average level of numeracy, problem solving ability, and financial literacy. The findings revealed that there is a significant and positive correlation between numeracy and financial literacy. Similarly, it was revealed that a substantial and direct relationship between problem-solving ability and financial literacy exists. Based on the results of the study, it is recommended that financial literacy may complement mathematics subject. The school and stakeholders may collaborate in providing number of training for teachers to help sustain student numeracy, problem-solving ability, and financial literacy.
\end{abstract}

\begin{tabular}{lll} 
Keywords Financial & Literacy, Numeracy, \\
Mathematics Problem Solving & \\
\hline
\end{tabular}

\section{Introduction}

Researchers and different organizations offer extensive range of conceptual and practical definitions of financial literacy. The Organization for Economic Cooperation and Development (OECD) defines financial literacy as the knowledge and understanding of the concepts and risks associated to financial aspects, together with the relative skills, motivation and confidence to apply such knowledge and understanding as basis of effective decision-making across the range of financial contexts, to improve the financial well-being of individuals and society, and to enable participation in economic life. Financial literacy is equally important to the young as it is to adults for they encounter several financial dilemmas that would affect their future lives. The financial choices that the younger generations are facing nowadays are far more challenging than those that have been experienced by the previous generations [2]. Furthermore, just as it was not possible to contribute to and thrive in an industrialized society without basic literacy such as reading and writing, so it is not possible to successfully navigate today's world without being financially literate. It can therefore be said that financial literacy is an essential skill in the 21 st century.

Low level of financial literacy in many countries results financial complexity of the modern world and the cost in well-being that derives from incorrect economic and financial decisions from an individual [3]. It has been found that the issue is especially important for young populations, which increasingly face major financial decisions. It will be useful to harness the school system - 
primary, secondary and tertiary levels and civil society for far more comprehensive coverage of financial education [4]. Hence, there is a need to incorporate financial literacy in education curricula.

In 2015, Republic Act 10679 also known as An Act Promoting Entrepreneurship and Financial Education Among Filipino Youth was signed by former President Benigno S. Aquino III to support financial literacy and financial education in the Philippines. Section 4 of the said Republic Act states that financial literacy program shall be inculcated in all levels of education nationwide. Consistent with Section 5 of Republic Act 10533, or the Enhance Basic Education Act of 2013, the Department of Education (DepEd) shall ensure that $\mathrm{K}$ to 12 Program curricula shall be supported by programs on financial literacy. In addition, DepEd Memorandum No. 544, s. 2008 , the institution partners with several private and commercial banks as spearheaded by Bangko Sentral ng Pilipinas (BSP) in launching the financial literacy program to develop habit and discipline of saving and money management among the Filipino youth. However, the given DepEd order only constitutes financial lessons integration on subject areas of Edukasyon sa Pagpapakatao (EP), Sibika at Kultura and Edukasyong Pantahanan at Panlipunan (EPP). Recently, Division Memorandum No. 032, s. 2019 supports the integration of economic and financial literacy in basic education in many subject areas including mathematics, specifically on the topics on statistics and probability. These movements predominantly support the significance of financial literacy t our country.

The connection between financial literacy and numeracy has paved its way since they relate to each other. For example, Lusardi [5] found that numeracy has an effect to the person's financial literacy in terms of financial socialization, quality of education and the study of economics. The mainspring, in order for one to become financially literate, is the capability in understanding numbers and having positive emotional attitude towards it which does not hinder an individual's daily engagement in activities involving mathematics and financial decision [6]. Hence, it can be mentioned that one of the contributing factors toward becoming financially literate may be explained by one's level of numerical proficiency. The numeracy of the student may serve as a computational engine which has various applications in the context of financial decision making.

In the Philippine $\mathrm{K}$ to 12 Education, the curriculum guide of Mathematics reiterated in its framework the importance of critical thinking and problem-solving skills as twin goals which are supported by other factors such as context, beliefs, environment, culture and language. In a study conducted by Attard [7] from a year six classroom in Australia, she explained how financial literacy and engagement in mathematics affect each other. Since the problems given involving money is relevant and purposeful to students' lives, they were engaged in problem solving in a real-life context rather than hypothetical situations. It shows how financial literacy and problem solving ideally works hand-in-hand towards improvement of one another. Researches nowadays show gaps on the degree of how problem solving is related to financial literacy especially in the Philippine setting.

Without an understanding of basic financial concepts, people are not well-equipped to make decisions related to financial management. People who are financially literate have the ability to make informed financial choices regarding saving, investing, borrowing, and more [8]. The benefits of better financial literacy may be great. On a personal level, individuals may save more, better manage risk and may even be general equilibrium effects. Financial literacy is one of the skills needed by learners today and gains curiosity of the topic as related studies in the country appears to be limited.

\section{Objectives of the Study}

This study examined the numeracy level, mathematics problem solving skills, and financial literacy among junior high school students. It also determined the significant association between student scores on these variables. The variables explored in this study were numeracy, problem solving, and financial literacy in terms of financial knowledge, financial behavior, and financial attitude.

\section{Materials and Methods}

\subsection{Research Design}

The Correlational Research Design was used in this study to describe and measure the degree of association or relationship between two or more variables or sets of scores [9]. This was used in the study with the scores on the numeracy level and mathematics problem solving skills of the respondents which were correlated to the scores on financial knowledge, financial behavior, and financial attitude as the domains of financial literacy.

\subsection{Population and Sample}

The study had a total sample size of 563 grade 9 and 10 students as the respondents from a population of five hundred ninety-eight (598) students. The sample size was computed using Cochran's Formula with a confidence level set at $99 \%$ and $1 \%$ margin of error. Many financial decisions are attributed in their age bracket as derived from the review of literature and it is beneficial to determine their financial literacy level because of its relevance to their daily lives. In addition, level of financial literacy was varied on different grade levels for several 
grade levels are taking or have already taken economics on their social studies subject so settling on a single grade level would not be advantageous. An application of multi - stage sampling had been used to determine the respondents of the study. They were grouped according to their school and in accordance to their grade level. A random sample from each stratum was taken in a number proportional to the stratum's size when compared to the population. These subsets of the strata were then pooled to form a random sample.

\subsection{Research Instrument}

The study used three distinct instruments to measure individually the numeracy skills, mathematics problem solving, and financial literacy of the respondents.

\section{Test on Numeracy}

The questions on the numeracy test are adopted from the Numeracy Inventory Tool for Laguna Learners (NIT2L) which consists of the basic topics that require mastery of skills in (1) Reading and Recognizing Numbers; (2) Ordering and Comparing of Numbers; (3) Performing Operations on Numbers; (4) Problem Solving \& Number Sense; and (5) Analyzing Patterns \& Graphs \& Handling Data. The forty (40) - item test comprises the combined and selected questions from Level 1 and Level 2 of the tool whose topics coverage are Whole Numbers, Integers, Rational Numbers and Decimals. The participants' level of numeracy was determined accordingly, based on the given scale of the tool: 35 - 40 Advance; 30 - 34 - Highly Numerate; 11 - 29 - Numerate; and $0-10-$ Low-numerate. It reported a reliability coefficient of $\alpha=.932$.

\section{Mathematics Problem-Solving Skills Test}

This instrument aims to assess the mathematics problem solving skills of the participants of the study. The five-item test was adopted from the instrument utilized by Siniguian [10] on the study "Students Difficulty in Solving Mathematical Problems". The questionnaire consists of word problems in mathematics such as age problem, time problem, motion or distance problem, number problem and geometry problem that will determine their process of problem solving. Steps of problem solving are identified by answering questions as (1) identifying what is asked and what are the given, (2) representing and forming mathematical equations, (3) computing or writing the solutions and (4) checking and stating the final answer. This is associated to the four phases of Polya's problem-solving. The difference on interpreting results is the use of a scoring scale. In this study, the researcher used the analytic scoring guide shown below to quantify the result of the respondents' problem-solving ability. The respondents' level of mathematics problem solving skill was determined accordingly based on four-level categorization. The following guide is used for descriptive interpretation: 35 $40=$ Very High; $30-34=$ High; $11-29=$ Average; and 0 $-10=$ Low. It obtained reliability coefficient of $\alpha=.917$.

\section{Test on Financial Literacy}

The goal of this test is to determine the level of financial literacy among the subject of the study. The literacy test is divided into three components namely financial knowledge, financial behavior, and financial attitude. For financial knowledge, five (5) of the questions were adopted from the Standards and Poors' Global Financial Literacy Survey. The additional seven (7) questions were adopted from the work of De Bock [11] which they have formed relative to Organization for Economic Co-operation and Development (OECD) goals on assessing financial literacy. The questions that have international currency were changed into Philippine peso given that the amount is not difficult enough to affect the main purpose of the instrument. In the worldwide study, an individual is perceived to be financially literate if he/she was able to answer three (3) out of four (4) questions which is $75 \%$. Hence, the respondents' level of financial literacy will be classified according to four-level of categories: $10-12=$ High; $7-9=$ Average; $4-6=$ Low; and $0-3=$ Very Low.

For financial behavior and financial attitude, a Likert scale adopted from Surendar \& Sarma [12] was utilized to measure the respondents' financial well-being on the said indicators with five (5) items each. It is answerable by using the scale from 1 (strongly disagree) to 4 (strongly agree). It generated a reliability coefficient of $\alpha=.951$.

To ensure the validity of the items and to guarantee that they are suitable and appropriate to the respondents of the study, these three (3) instruments were validated by a group of five (5) experts consisting of two mathematics master teachers, mathematics head teacher, district mathematics principal coordinator for high school and a professor from the College of Business Management and Accountancy. Remarks column were also provided for their comments, points for revisions, corrections, and recommendations on item content and construct. These experts rated the instruments as highly acceptable. After the pilot-testing, the instruments reported an overall reliability index of $\alpha=0.940$.

After the instruments were administered to the respondents, the collected data were organized, tallied, and analyzed using frequency, percent, mean, and Pearson Product Moment of Correlation Coefficient.

\section{Results and Discussion}

Locally, the Division of Laguna under the Department of Education - Region IV-A initiated its means of determining the numeracy level of the public school students in the province by devising a tool called NIT2L (Numeracy Inventory Tool for Laguna Learners) which 
consists of the basic topics that require mastery of skills in (1) Reading and Recognizing Numbers; (2) Ordering and Comparing of Numbers; (3) Performing Operations on Numbers; (4) Problem Solving \& Number Sense; and (5) Analyzing Patterns \& Graphs \& Handling Data. This tool categorizes students as advanced, highly numerate, numerate and non-numerate depending on the obtained score.

Table 1. The Respondent's Numeracy Level

\begin{tabular}{cccc}
\hline Level & Frequency & Percent & Mean \\
\hline Advanced & 83 & 14.74 & \\
Highly Numerate & 79 & 14.03 & \\
Numerate & 371 & 65.90 & 24.19 \\
Low Numerate & 30 & 5.33 & \\
Total & 563 & 100.00 & \\
\hline
\end{tabular}

As shown in Table 1, more than half of the respondents are considered to be numerate with a frequency of 371 $(65.9 \%)$ and more than a quarter of them have advanced and high level rating with frequencies 83 (14.74\%) and 79 (14.03\%), respectively of the basic numerical skills such as reading, recognizing, ordering and comparing numbers, performing operations and analyzing patterns, graph or data on topics such as whole numbers, integers, rational numbers and decimals.

Only 30 or $5.33 \%$ of the respondents were found to have low level of numeracy. The obtained mean for numeracy scores is 24.19 which is considerably not too soaring relative to their grade level. However, a good result of $95 \%$ of numerate students given the tool of the Division is something to be regarded too.

According to Imam [13], Mathematics education in the Philippines is one of the priority concerns of the Department of Education (DepEd). This is due to the results being given by the different body analyzing the mathematics proficiency of Filipino students - both in international and national studies. One recent example of this is the result of PISA 2018 National Report of the Philippines which explored the reading, mathematics and scientific proficiency of high school students in comparison to other countries. The result of mathematics proficiency test among the surveyed students revealed a low mean score of 353 points which is a little point below the level 1 proficiency score of 358 and significantly lower than the OECD average (489 points) and ASEAN countries. At level 1, students can answer only the question with a similar context and clearly defined immediately come after a discussion of a mathematics concept. Moreover, the result shows that Philippines ranked lower than neighboring countries. Because of these, many initiatives on recognizing these problems have risen in the previous years from different regions or divisions.
Table 2. The Respondent's Problem-solving Skill Level

\begin{tabular}{ccc}
\hline Level & Frequency & Percent \\
\hline Very High & 1 & 0.18 \\
High & 6 & 1.07 \\
Average & 382 & 67.85 \\
Low & 174 & 30.90 \\
Total & 563 & 100.00 \\
\hline
\end{tabular}

The results in Table 2 revealed a dominating average level of problem-solving skills among the respondents with a frequency of $382(67.85 \%)$. This means many of them scored from 11 to 29 from a total of 40 points. This is followed by the respondents whose classification is low with a frequency of $174(30.90 \%)$. Unlike the numeracy level, their problem-solving skills level seemed significantly lower with $30.90 \%$ of them having low level of problem-solving ability. This outcome is also supported by the mean score of 12.57 among the collected data from the students. This is upsetting since one of the twin goals of the present curriculum in mathematics is to develop the problem-solving ability of students.

Recently, the PISA [14] National Report of the Philippines has come out all over the news reporting the reading, mathematics and scientific proficiency among Filipino students in comparison with other countries. Results revealed that the average score of students is 353 points and sadly, they were classified a little below Level 1 proficiency. At level 1, students were able to answer only the questions with similar context and clearly defined. This pertains to routine problems they usually encounter in classroom that require obvious actions and follow immediately from the given. Moreover, only 1 out of 5 students attained at least minimum proficiency level (Level 2) and Philippines performed significantly lower than the OECD average (489 points) and ASEAN countries.

The results of this study exhibited the same findings for both numeracy and mathematics problem solving among the surveyed students. Yet, the contributing factor/s of these problems is another topic to be found out, analyzed, and discussed.

Financial knowledge is the first construct of financial literacy that refers to how an individual understands the basic knowledge on financial concepts. In this study, the financial concepts involved are the understanding on inflation, risk diversification, simple and compound interest.

Table 3. The Respondent's Level of Financial Knowledge

\begin{tabular}{ccc}
\hline Level & Frequency & Percent \\
\hline High & 25 & 4.44 \\
Average & 150 & 26.64 \\
Low & 295 & 52.40 \\
Very Low & 93 & 16.52 \\
Total & 583 & 100.00 \\
\hline
\end{tabular}


It is evident from Table 3 that more than half of the respondents have low level of financial knowledge with a frequency of $295(52.40 \%)$. This means many of them scored lower than 7 in the 12-item questionnaire of the topic. This is followed by the students whose level of financial knowledge is average with $150(26.64 \%)$ count. Ninety-three $(16.52 \%)$ respondents were found to have very low financial knowledge and only $25(4.44 \%)$ of the surveyed individuals have high level of knowledge on finances based on the given tool.

For financial knowledge, the mean score obtained is 5.47 which also fall under the low-level range. If we put it into a mean percentage score, $45.58 \%$ will be obtained which is lower than the requirement of at least $75 \%$. From Table 2, it can be concluded that only 3 out of 10 students have enough knowledge on finances.

Hence, it can be inferred that there is a low level of financial knowledge among students that needs to be worked on. This outcome supports the presented report on 2014 Standard and Poor's Financial Literacy survey where it was mentioned that only $25 \%$ of the surveyed Filipino adults were found to be financially literate. Llanto and Rosellon [15] also revealed figures on problems of Filipinos when it comes to finances that could be avoided given there is a strong foundation of financial knowledge.

Financial behavior, as used as the second subscale of financial literacy, is defined as the process of how individuals understand and act on financial knowledge so as to make sound investment decisions. In this research, a scale is used to measure financial behavior, which involves the factors that affect their actions or inactions in terms of financial aspect.

Table 4. The Respondent's Level of Financial Behavior

\begin{tabular}{lcc}
\hline \multicolumn{1}{c}{ Statement } & Mean & $\begin{array}{l}\text { Descriptive } \\
\text { Equivalent }\end{array}$ \\
\hline $\begin{array}{l}\text { 1. I have financial goals in terms of } \\
\text { short-term (less than 1 year)/ } \\
\text { long-term (more than a year) }\end{array}$ & 3.23 & Average \\
$\begin{array}{l}\text { 2. I have my own financial plan and } \\
\text { I strictly go accordingly }\end{array}$ & 2.96 & Average \\
$\begin{array}{l}\text { 3. Before I buy something, I } \\
\text { consider whether I can afford it. } \\
\text { 4. I consider several products from } \\
\text { different companies before making } \\
\text { the decision to buy. }\end{array}$ & 3.50 & High \\
$\begin{array}{l}\text { 5. I keep close personal watch on } \\
\text { my financial affairs. }\end{array}$ & 3.15 & Average \\
\hline \multicolumn{1}{c}{ Composite } & 3.17 & Average \\
\hline
\end{tabular}

Generally, the students have good financial behavior as exhibited in Table 4 where they obtained average scores on having financial goals, planning and deciding on their financial dealings and keeping a watch of their financial affairs. Eliciting positive behavior in managing their finances at a young age is an admirable thing to be identified. Although their financial knowledge appeared to be low in summary, this doesn't seem parallel to their financial behavior. It can be observed from Table 4 that among the statements, the one that stood out is considering the capability of buying a particular thing before spending their money. Overall, there is an average level of financial behavior among the respondents of the study. This implies that most of the students nowadays have identified the importance of financial decisions and management.

Financial literacy has gained the attention of the public as financial challenges of modern world emerge constantly. The financial preparedness of the youth must be addressed for it is vital in the economic future. The importance of being financially literate at an early age makes them ready to make financial decisions and navigate the increasingly complex financial marketplace [16]. People who are financially literate have the ability to make informed financial choices regarding saving, investing, borrowing and more [17].

Financial attitude on the other hand is the third domain of financial literacy which is the reflection of an individual's preferences in terms of finance in the future.

Table 5. The Respondent's Level of Financial Attitude

\begin{tabular}{lcc}
\hline \multicolumn{1}{c}{ Statement } & Mean & $\begin{array}{c}\text { Descriptive } \\
\text { Equivalent }\end{array}$ \\
\hline $\begin{array}{l}\text { 1. I find more satisfying to save } \\
\text { money for the future than to spend. }\end{array}$ & 2.67 & Average \\
$\begin{array}{l}\text { 2. I believe in developing a regular } \\
\text { pattern of saving and stick to it. }\end{array}$ & 2.65 & Average \\
$\begin{array}{l}\text { 3. Saving money for future use is } \\
\text { more important than spending it } \\
\text { today. }\end{array}$ & 2.78 & Average \\
$\begin{array}{l}\text { 4. The length of time it will take me } \\
\text { to pay off outstanding debts must be } \\
\text { considered. }\end{array}$ & 2.87 & Average \\
$\begin{array}{l}\text { 5. The amount money to be saved is } \\
\text { also important. }\end{array}$ & 2.99 & Average \\
\hline \multicolumn{1}{c}{ Composite } & 2.77 & Average \\
\hline
\end{tabular}

It can be viewed in Table 5 that an average of surveyed individuals believes in developing a pattern of saving although they find it more satisfying to spend than save money for the future. It is good to know with the result of statements 3 and 4 that students' perception on the importance of saving and length of time a debt should be paid is positive. Statements 5 seemed to be the most pronounced than the other statements which means as saving is important to the students, the amount to be stored is not as important.

In general, an overall score of 2.77 which fall under the average level is identified among the respondents. This means an average number of students has positive reflection on future undertakings in future finances.

The purpose of financial literacy is not solely for knowledge and understanding but rather in promoting effective decision making. Second, the objective of financial literacy is to improve financial well-being. Third, this concept does not affect an individual only but society as well. Fourth, financial literacy, just like the basic knowledge that formal education currently teaches us and 
enables young people to participate in economic life [5].

Table 6. Significant relationship between numeracy and financial literacy

\begin{tabular}{ccc}
\hline \multirow{2}{*}{ Financial Literacy } & \multicolumn{2}{c}{ Numeracy } \\
\cline { 2 - 3 } & $r-$ value & Strength \\
\hline Financial knowledge & $.609^{* *}$ & Moderate \\
Financial behavior & $.296^{* *}$ & Low \\
Financial attitude & $.356^{* *}$ & Low \\
\hline
\end{tabular}

**Significant at .01 level

It can be gleaned from Table 6 that the correlation between financial behavior and numeracy is definite but small $(r=.296 ; p<.01)$. Similarly, there is low positive correlation between financial attitude and numeracy ( $\mathrm{r}$ $=.356 ; \mathrm{p}<.01)$. Moreover, there is a moderate and positive relationship between financial knowledge and numeracy $(\mathrm{r}=.609 ; \mathrm{p}<.01)$. Consequently, as numeracy level increases, the level of financial literacy tends to increase also. Regarding the strength of relationship, it can be inferred that there is practically significant correlation between numeracy and financial literacy.

These results confirm the presented literatures telling that there is a significant relationship between financial literacy and numeracy. To mention again, Lusardi [5] concluded on her paper that there is a link between financial literacy and numeracy. Amezcua and Everardo [3] also highlighted the direct relationship between mathematics and financial literacy as their study indicated that increase in financial literacy rate is also an increase in math score.

Table 7. Significant relationship between problem-solving skill and financial literacy

\begin{tabular}{ccc}
\hline \multirow{2}{*}{ Financial Literacy } & \multicolumn{2}{c}{ Problem-solving } \\
\cline { 2 - 3 } & $\boldsymbol{r}-$ value & Strength \\
\hline Financial knowledge & $.563^{* *}$ & Moderate \\
Financial behavior & $.190^{* *}$ & Low \\
Financial attitude & $.214^{* *}$ & Low \\
\hline
\end{tabular}

**Significant at .01 level

Table 7 showed the significant relationship among the constructs of financial literacy and problem-solving ability. It is visible that the results presented were statistically significant with each other. Similar to the strength of relationship between numeracy and the domains of financial literacy, problem-solving ability marked a definite but small correlation to financial attitude and behavior. A moderate correlation was also found between problem-solving and financial knowledge. It supports the presented studies like that of the result in Amezcua and Everardo [3] where they noticed that an increase of correct response in mathematics question results an increase also in financial literacy rate by 0.12 standard deviations. They emphasized the direct relationship between mathematics ability of the students and financial literacy. The positive correlations between problem-solving ability and financial literacy with respect to financial knowledge, behavior and attitude means that a financially literate student is also a good problem-solver [17].

\section{Conclusions and Recommendations}

The numeracy and financial literacy of the students have positive correlation. It can be said that as the numeracy improves, the financial literacy rate varies directly with it. The study also concluded that there is a significant relationship between mathematics problem solving and financial literacy components among junior high school students. The students' mathematics problem solving ability and numeracy are directly associated to financial literacy. It can be deduced that a numerate and good problem-solver student are also financially literate. Therefore, it is recommended that the administrators may improve the existing programs that concern financial literacy supported by mathematics education. The teachers may collaborate with one another on how to integrate financial knowledge with mathematics education with classroom tasks and activities. The school and other governing stakeholders may provide trainings and workshops to help improve this matter. Lastly, for future researchers, they may have to conduct action researches on models and activities that would help the administrators, teachers and students address this national concern.

\section{Acknowledgments}

The authors would like to acknowledge the Graduate School of the College of Teacher Education, Laguna State Polytechnic University, for the technical assistance provided for the completion of this study.

\section{REFERENCES}

[1] Organization for Economic Cooperation Development (2019). PISA 2021 Financial Literacy Analytical and Assessment Framework. Retrieved from: https://www.oecd.org/pisa/sitedocument/PISA-2021-financi al-literacy-framework.pdf

[2] Lusardi, A. (2015). Financial Literacy Skills for the 21st Century: Evidence from PISA. The Journal of Consumer Affairs, 49 (3).

[3] Amezcua, A. V., \& Everardo, J. A. (2017). Financial Literacy and Mathematics: A Study among Young Mexican High School Students. Revisita Mexicana de Economia y Finanzas, 12 (2), 1-22. 
[4] Llanto, G. M. (2015). Financial Inclusion, Education, and Regulation in the Philippines. ADBI Working Paper 541. Tokyo: Asian Development Bank Institute. Retrieved from: http://www.adb.org/publications/financial-inclusion-educati on-and-regulation-philippines

[5] Lusardi, A. (2012). Numeracy, Financial Literacy, and Financial Decision-Making. National Bureau of Economic Research .

[6] Skagerlund, K., Lind, T., Stromback, C., Tinghog, G., \& Vastfjall, D. (2018). Financial Literacy and the role of numeracy - How individuals' attitude and affinity with numbers influence financial literacy. Journal of Behavioral and Experimental Economics, 18-25.

[7] Attard, C. (2016). Mathematics + Money = Engagement: Financial Literacy as a Tool to Increase Opportunity and Engagement with Mathematics for Students from Low Socio-Economic Areas. Retrieved from Penrith: https://www.moneysmart.gov.au/media/560516/moneymath ematicsengagement_final_report_14_september_2016-asso c-prof-catherine-attard.pdfMackenzie, R. $\overline{\text { J }}$ (2018). One-Way vs Two-Way ANOVA: Differences, Assumptions and Hypotheses

[8] Klapper, L., Lusardi, A., \& Oudheusden, P. v. (2014). Financial Literacy Around the World: Insights from the Standard \& Poor's Ratings Services Global Financial Literacy Survey.

[9] Creswell, J. (2014). Research design: Qualitative, quantitative, and mixed methods approaches. 4th Ed. Los Angeles, California, USA: SAGE Publication, Inc.
[10] Siniguian, M. (2017). Students Difficulty in Solving Mathematical Problems. International Journal of Advanced Research in Engineering and Applied Sciences. Vol. 6. No. 2.

[11] De Bock, D., De Win, I., \& Campenhout, G. V. (2019). Inclusion of Financial Literacy Goals in Secondary School Curricula: Role of Financial Mathematics. Mediterranean Journal for Research in Mathematics Education, 16, 33-52.

[12] Surendar, G., \& Sarma, V.V., (2018). Financial Literacy and Financial Planning Among Teachers of Higher Education - A Study of Critical Factors of Select Variables. International Journal of Pure and Applied Mathematics

[13] Imam, O. (2013). Reading Predictors Students Performance in Mathematics and Science Notre Dame University Cotabato City.

[14] Programme for International Student Assessment (PISA) (2018.) Retrieved from: https://www.oecd.org/pisa/publicat ions/pisa-2018-results.htm

[15] Llanto, G. M., \& Rosellon, M. A. (2017). What Determines Financial Inclusion in the Philippines? Evidence from a National Baseline Survey. Philippine Institute for Development Studies

[16] Yoshino, N., P. Morgan, and G. Wignaraja. (2015). Financial Education in Asia: Assessment and Recommendations. ADBI Working Paper 534. Tokyo: Asian Development Bank Institute.

[17] Kayoda, Y., \& Khan, M. S.(2016). Explaining Financial Literacy in Japan: New Evidence using Financial Knowledge, Behavior and Attitude. 